\title{
RANDOM NOTES FROM THE SECRETARIAT
}

Members of the Congress have no doubt observed the increase in the number of pages in the current numbers of the Bulletin. This emphasizes the continuing growth of this publication and its increasing importance to the expanding mathematical community. For the benefit of new members, it might be noted that this publication began as a newsletter in 1954 chiefly through the efforts of Professor Peter Scherk of the University of Toronto, who was then at the University of Saskatchewan. The newsletter continued for four years and then was replaced by the Bulletin in its present form, with a 70-page issue in January, 1958. A great deal of credit goes to the present editor and managing editor for their interest and energetic efforts in bringing the publication to its present status.

The response from mathematicians regarding membership, including subscription to the Bulletin, has been most satisfactory. About two-thirds of our membership of about five hundred have responded and most of the se have sent in any unpaid dues that were outstanding. The names of twenty-seven former members who were two or more years in arrears and who did not reply, were removed from the list. Our apologies go to any of our members who may have received a considerably delayed acknowledgement of their payment. The number of acknowledgements proved too much for our staff to handle immediately, along with keeping up with our many activities. However, very little delay was incurred in the dispatch of the first is sue of Volume 6 to the fifty new members. Any of the back numbers can also be obtained by writing to the Secretariat and enclosing the cost of $\$ 1.00$ per copy.

The programme for the June meetings is now completed and we hope that many of our members will attend them at the Conference of Learned Societies to be held at Laval University. Professor Leo Moser of the University of Alberta will give an address on "Semi-analytic Number Theory" on Saturday morning, June 1. He will be followed by Professor L.J. Mordell who will speak on "Some New Results on Diophantine Equations". The Council of the Canadian Mathematical Congress will meet on Saturday afternoon and a subscription dinner will be held in the evening for mathematicians and their wives. Fifteen papers have already been sent in for presentation on Tuesday, June 4, and Wednesday, June 5 .

Plans for the seminar, colloquium and congress are proceeding satisfactorily and all signs point towards a most successful and interesting series of meetings. We are fortunate indeed to obtain such excellent lecturers and to have Professor Alfréd Rényi of Hungary as the chairman 
of the colloquium. All those in attendance will also look forward to the final event of the congress when they will be the guests of the Province of Saskatchewan at a dinner to be held in the Bessborough Hotel in Saskatoon. Members have already been sent all the relevant information but any further information can be obtained from the secretariat.

A summary account of our audited statement for the year 1962 including all Congress activities, is given below:

\section{Income from Various Sources}

1. Business and Industry in the various provinces (for the general fund)

British Columbia ................ \$ 925

Alberta ................ 3,095

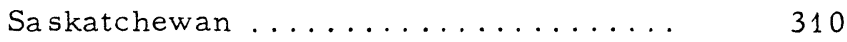

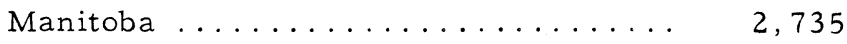

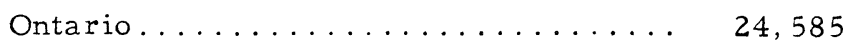

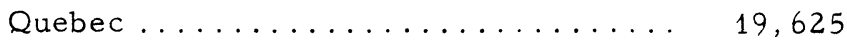

New Brunswick ............... 500

Nova Scotia ................. 850

$\$ 52,625$

2. National Research Council

For the General Fund ........... \$24,000

For the Summer Re search Institute... 30,000

For the Journal ..................... 6,000

For the Bulletin ............ 3, 500

For the 1962 International Congress ... 5, 000

$\$ 68,500$

3. Atlantic Provinces Scholarship Funds:

New Brunswick.............. \$2,970

Nova Scotia .............. 2, 315

$\$ 5,285$

4. Canadian Universities (For the Journal) ..........6, 6, 075

5. American Mathematical Society (For the Journal) ..... 1,150

6. Province of Nova Scotia (For the Summer School) ..... 2,500

7. International Nickel Company (For the Summer School). 5,000

8. Membership Fees.................... 1,400

9. Subscriptions to the Bulletin ............... 694

10. Books and Publications (net) .............. 352 
NOTE: The general fund of the Congress includes all accounts except the Summer Research Institute, the Canadian Journal of Mathematics, the Scholarship Funds for New Brunswick, Nova Scotia and South Africa and the Endowment Fund.

The following table gives some comparison between the se contributions in 1961 and 1962.

$$
\begin{aligned}
& 1961 \quad \underline{1962} \\
& \text { Number of increases from continuing contributors . } 18 \quad 24 \\
& \text { Number of decreases from continuing contributors. . } 499
\end{aligned}
$$

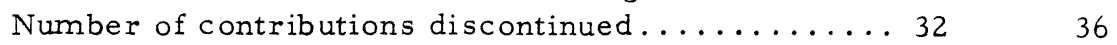

$$
\begin{aligned}
& \text { Number of new contributors .............. } 33 \quad 25 \\
& \text { Net increase over the previous year in the } \\
& \text { total of the se contributions } \ldots \ldots \ldots \ldots \ldots \ldots \$ 1,650 \quad \$ 1,530
\end{aligned}
$$

Item (2) represents an increase of $\$ 8,500$ over the 1961 grant from the National Research Council. This was distributed as follows:

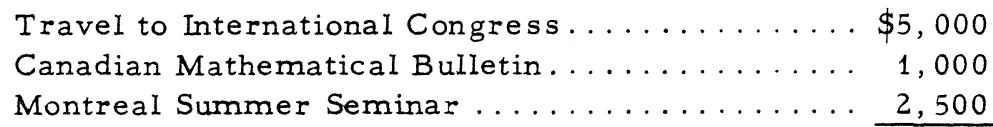
$\$ 8,500$

\begin{tabular}{|c|c|}
\hline & \\
\hline 年 & 2,06 \\
\hline & \\
\hline 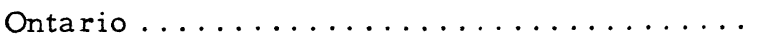 & 5, \\
\hline$\ldots \ldots \ldots \ldots \ldots \ldots \ldots$ & 3 , \\
\hline . & 3,69 \\
\hline$\ldots \ldots \ldots \ldots \ldots \ldots \ldots \ldots$ & 3,63 \\
\hline$\ldots \ldots \ldots \ldots \ldots \ldots \ldots \ldots$ & \\
\hline & \\
\hline
\end{tabular}

\section{Disbursements}

1. Administration, Supplies and Overhead (including travelling expenses for the administrative officers and other members to promote the various activities) .........

2. Scholarships, Bursaries and Prizes in the various provinces 
3. Summer Research Institute $\ldots \ldots \ldots \ldots \ldots \ldots \ldots \ldots \ldots, 000$

4. Canadian Journal of Mathematics ........... 13,225

5. Atlantic Provinces Summer School ............. 5, 272

6. 1962 International Congress Grants ........... 15, 383

7. Canadian Mathematical Bulletin ........... 4, 770

8. Grants for Individual Study and Rè search ........ 7,618

9. Membership Fees in Organizations ............. 412

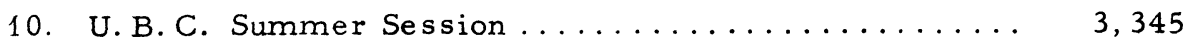

11. Montreal Summer Seminar ............... $\frac{10,256}{\$ 142,317}$ $\$ 142,317$

In the statement above, the amount of $\$ 30,000$ for the Summer Research Institute was received in our General Fund and then paid into the Institute fund. The statement for this fund follows:

Balance at credit of Fund December 31 st, $1961 \ldots \ldots \$ \$ 9,655.21$ INCOME YEAR 1962

Grants from National Research Council......... $\frac{30,000.00}{\$ 39,655.21}$

DISBURSEMENTS YEAR 1962

Grants to Mathematicians including

travelling expense allowances.....\$23,976.13

Secretarial expense ............ 384.54

Entertaining expense ........... 279.83

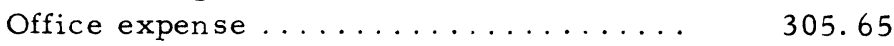

Publishing Institute Reports ........ 80.57

DISBURSEMENTS TOTAL

Balance at credit of Fund December 31st, $1962 \quad \$ 14,628.49$

The Canadian Journal of Mathematics Sustaining Fund was set up to ensure future publications.

Balance at credit of Fund, December 31 st, 1961 ... 3, 313.90

Amount received for credit to Fund, year $1962 \ldots \ldots$. 75.00

Balance at credit of Fund, December 31 st, 1962 $\$ 3,488.90$

The budget for 1963 provides for disbursements amounting to over $\$ 158,000$, an increase of more than $\$ 16,000$ over the disbursements in 1962. Of this increase, $\$ 10,000$ will go to the Summer Research Institut from the corresponding increase in the National Research Council Grant for this purpose. 